\title{
Endocrine disrupting chemicals vs longevity in the COVID-19 era: Public health implications
}

\author{
'Evangelos A Polychronopoulos, \\ ${ }^{1}$ George K Balias, 'Maria G \\ Skouroliakou, 'Chrysa Kapartziani, \\ 1,3Paraskevi D Kalofiri, ${ }^{2}$ Michail Rallis \\ ${ }^{1}$ Harokopio University, Department of Nutrition \\ and Dietetics \\ ${ }^{1}$ Harokopio University, Department of \\ Geography \\ ${ }^{2}$ National and Kapodistrian University, \\ Department of Pharmaceutics \\ ${ }^{3}$ University of West Attica, Department of \\ Biomedical Sciences \\ Corresponding author: \\ Evangelos A Polychronopoulos \\ Odysseos 43, Voula, 16673 Athens, Greece \\ E-mail address: \\ epolychronopoulos50@gmail.com \\ Received 10 November 2020 \\ Accepted 22 December 2020
}

\begin{abstract}
Endocrine disrupting chemicals (EDCS) are a controversial topic within scientific, regulatory, socio-economic, and public health circles. Nonetheless, every community's physical environment is currently under siege from various EDCs, many of which are still unknown. EDCs affect the normal function of the endocrine, neurological, and immune systems, consequently diminishing successful development, reproductive adulthood, and decreasing survival. Beyond any doubt, adverse effects of EDCs are a consequence of multiple everyday exposures to hundreds of chemicals in unknown environmental doses such as pesticides, insecticides, polycyclic aromatic hydrocarbons, dioxins, polychlorinated biphenyls, dichlorodiphenyltrichloroethane, brominated flame retardants, and parabens. Considering that thousands of other known endocrine disruptors fly under the radar of scientific and medical communities due to existing methodological pitfalls, the situation is quite precarious. In 2012, the World Health Organization published a report emphasizing that EDCs are a major and emerging global public health threat. The combined power of informed consumers, industry innovations, and government regulations is the driving force in this fight. Therefore, research advancements, public health infrastructure, and environmental protection agencies are the fundamental pillars in combating the ever-growing issue of EDCs.
\end{abstract}

Key words: Endocrine disrupting chemicals; Public health; COVID-19.

\section{HEALTH HAZARDS ASSOCIATED WITH EXPOSURE TO EDCS}

Endocrine disrupting chemicals (EDCs) and potential EDCs are controversial issues within scientific, regulatory, socio-economic, and public health fields. The physical environment in every community is currently under siege from EDCs. These substances hide a pernicious threat to the health of future and present generations. EDCs significantly impact wildlife and human health, affecting the endocrine system's normal function, consequently diminishing the successful development, reproductive adulthood, and decreasing survival $[1,2]$. According to a World Health Organisation (WHO) report, an endocrine disruptor is an exogenous substance or mixture that alters function(s) of the endocrine system and subsequently causes adverse health effects in an intact organism or its progeny or (sub)populations [3]. Endocrine disruption is a complicated environmental and medical issue with mostly unknown consequences. Hundreds of chemicals fall under the class of endocrine disruptors, including pesticides, nutrients, food additives, natural and industrial substances such as polycyclic aromatic hydrocarbons (PAHs), polychlorinated biphenyls (PCBs), dioxins, dichlorodiphenyltrichloroethane (DDT), brominates flame retardants (BFRs), parabens, as well as complex chemical mixtures in multiple environmental doses. This issue is further complicated by interactions between biological structures and EDCs, such as nutrient-diet-EDCs interactions and gene-nutrient-EDCs interactions. EDS exposure affects all stages of human development and virtually all organ systems. Altered puberty, preterm birth, low birth weight, infertility, and premature menopause have all been associated with EDCs. Some of the dysfunctions and diseases associated with early exposure to EDCs include atherosclerosis, cardiovascular disease, thyroid dysfunction, allergy, asthma, increased infections morbidity, low semen quality, testicular dysgenesis syndrome, geni- 
tal malformations, hypospadias, learning difficulties, autism, Alzheimer's disease, and endocrine-related cancers (ovarian, endometrial, breast, prostate, testicular, thyroid cancer, lymphomas, and leukaemia $[4,5]$. Manifestations of EDC's early symptoms are difficult to describe due to the large presence of these chemicals in the air, water (lakes, rivers), and everyday food sources. The disruption effects on the normal endocrine system's function are related to a critical period concerning a development window during which genes, programmed by endocrine signals, regulate tissue functioning. Concerning children's development and examining exposure-response relationships from conception to puberty, several factors must be considered, including multiple exposure routes, time characteristics, frequency, qualitative and quantitative data, validated sampling, proper storage, and selected analytic methods [6]. The evidence linking cause and effect is abundant for several categories of chemicals, while we know of at least a thousand more endocrine disruptors. Considering that many chemicals have not been tested and somewhat fly under the radar of both scientists and the medical community, the situation is quite precarious. It is imperative to illuminate the mechanisms of endocrine system function, and how the ECDs affect the endocrine systems, the correlation between exposure windows, and disease incidence.

Concerning longevity, EDCs endocrine function alteration action probably has been counteracted by determinants of longevity, including immune response, heredity, genetic susceptibility, socio-demographic, clinical, psychological, and lifestyle characteristics. All of these contribute to successful generations, from reduced exposure to EDCs in remote and isolated areas, healthy childhood, healthy adulthood, and 'successful' aging and its relation to the reduction of chronic diseases risk (oxidative stress, inflammation, CVD, cancer, depression), contributing to the ideal 'free of disease' life at all ages including older individuals (>65 years) living in Mediterranean islands (Lessons From Medis Elderly Free of Disease Study) [7].

\section{COVID-19 ERA}

Due to long-term effects, the EDCs issue probably belongs to unidentified, underlying causes of COVID-19 pandemic, contributing to increased morbidity, high incidence rate, high mortality rate (MR), and case fatality rate (CFR). It poses an additional unknown impact on sensitive population groups and individuals' health during the COVID-19 pandemic. Environmental EDCs chronic low-level exposure is associated with increased morbidity in chronic, non-communicable diseases, diabetes, obesity, cancer, CVD, with millions of deaths every year worldwide. Chronic diseases increase the sensitivity and vulnerability to COVID-19 of older individuals, particularly, with underlying health conditions.

Coronavirus has been studied from the 60s [8,9]. Very impressive COVID-19 prevention measures have been implemented in China, Wuhan, where COVID-19 initiation was followed with strict hygiene rules, continuous masks use, and complete home isolation for short time intervals. Furthermore, the COVID-19 pandemic has spread worldwide, with the death toll in Europe (Pergamo), the USA, and all continents. Apparently, public health authorities, scientific medical professionals (doctors and nurses) have been combining the continuing preventive actions, implementing simultaneously, update patient care in intensive care units, advising the susceptible population to implement safety and hygiene measures (i.e., masks, which have been used for 100 years in Japan) [9].

Nevertheless, limited attention or priority is given by medical staff and emergency COVID-19 medical committees to chronic EDCs unknown level exposure, which contributes to increased morbidity in chronic, non-communicable diseases, thyroid dysfunction, diabetes, obesity, cancer, and CVD [10]. Furthermore, chronic diseases increase the sensitivity and vulnerability to COVID-19 of older individuals, particularly, with underlying health conditions. Presumably, the great aim of the developed western societies is to maintain the high public health living standards and to protect the sensitive population groups during the COVID-19 pandemic by implementing prevention at all levels: primordial, primary (vaccination), secondary (mass screening), tertiary (palliative care), quaternary (monitoring polypharmacy, over diagnostics), and last but not least, critical patient care: primary, secondary, tertiary, triage, intensive care unit, recovery from the optimist point of view.

Moreover, the necessity for registry improvement and adaptation is apparent: Greece vs. Serbia National Environmental Endocrine Disruptors Registries (EDCs, Disease Burden Registry), in the context of European patterns Disease Registries (Cancer Registry), the first Priority is COVID-19 Pandemic Registry.

\section{OVERVIEW OF THE METHODOLOGY USED TO STUDY EDCS}

There are several significant issues in our current methodological approach to the study of EDCs. First, the vast majority of current commercial chemicals have not been safety-tested regarding their potential for endocrine disruption [11]. Even when specific chemicals are being tested, often there are numerous methodological pitfalls like not correlating observable effects with examined doses during validated guideline studies. Second, doses that have been declared safe have not been actually tested, nor were the most commonly 


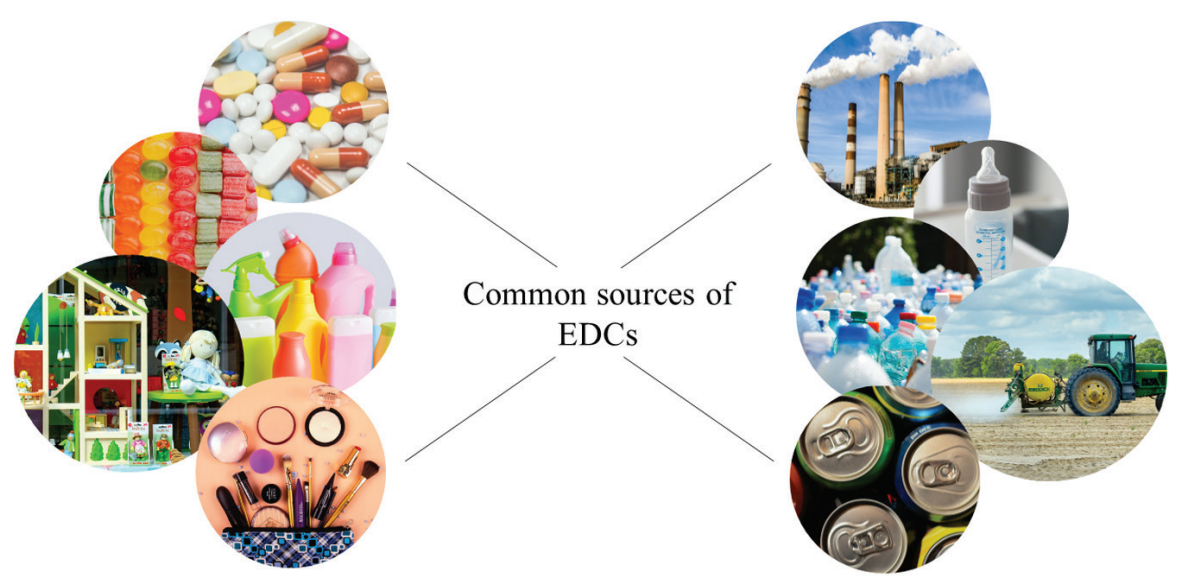

Scheme 1. Common potential sources of endocrine disrupting chemicals (EDCs): pesticides, nutrients, food additives, polycyclic aromatic hydrocarbons, polychlorinated biphenyls, dioxins, dichlorodiphenyltrichloroethane, brominates flame retardants, parabens, plastic bottles, metal food cans, harmful household detergents, toys, drugs, cosmetics, and nutrient interactions..

used mixtures of EDCs [12]. Third, procedures and criteria for EDCs classification remain obscure. For example, a well-known and very common EDC found in children's toys, dental material, beverage and food containers, plastic bottles, and cans inner coating - BPA has been classified as an environmental xenoestrogen due to its ability to stimulate the estrogen receptor. However, BPA also affects the immune system function in allergies and asthma, although there is no clear consensus about the underlying mechanisms (4). EU regulations No. 2017/2100 and 528/2012 indicate specific criteria for defining endocrine disruptors' properties as biocides, while intergenerational registries store such information (6).

Furthermore, one of the primary identification problems from the pathophysiology point of view is the impact of EDCs when acting as unknown mixtures in unknown doses due to passive absorption through airways and skin throughout the day. Therefore, one of the research laboratories' most fundamental goals should be testing the mixtures of chemicals, especially the ones affecting the thyroid gland axis and their impact on various metabolic and pathophysiological processes $[13,14]$. Another essential issue to be considered when studying the impact of EDCs is the non-monotonic dose-response (NMDR), concerning no predictable or typical dose-response pathways (increasing dose, increasing response) of EDCs. In other words, NMDR creates unusual curves (U shapes or inverted $U$ shape), meaning a more significant response is achieved at lower than higher doses of EDCs $[15,16]$ whole organ cultures, laboratory animals and human populations. The mechanisms responsible for these NMDRCs are well known, typically related to the interactions between the ligand (hormone or EDC. Moreover, as stated in one consensus statement about the endocrine disruption, we must act beyond one chemical, one dose, one disease at a time [11]. As the pat- tern for a good methodological approach, a lesson can be learned from Canada, where the Canadian Health Measures Survey measured more than 250 chemicals in the blood, urine, and hair samples of thousands of Canadians.

Most commonly used methods for EDCs testing include laboratory studies on animals, endocrine disruptors screening program constituted by the Environmental Protection Agency (Tier 1 and Tier 2 screening assays), and a multigenerational protocol for the detection of short-term and long-term effects [15]. Tier 1 identifies a substance's potential to interact with the endocrine system, whereas Tier 2 further identifies and characterizes chemical-induced interactions with estrogen, androgen, and thyroid hormones for risk assessment in order to directly inform regulatory decisions. According to one interlaboratory study that used various assays to dissect the effects of EDCs mixtures in samples of multiple contaminants concluded that the expected additive mixture response did not occur due to masking effects by general toxicity from various compounds $[13,14]$. When studying EDCs, it is important to take into account Tier 2 tests' strengths and weaknesses as much as the industry's perspectives concerning regulations. Other than these conventional methods, various databases are now available to aid in EDCs research, such as Computational Toxicology Tools, EDCs DATA BANK, EDCs Intergenerational Registries at National, European and Transatlantic Level.

\section{HOW SHOULD WE PROCEED REGARDING EDCS RESEARCH AND RAISING PUBLIC AWARENESS}

In 2012, the World Health Organization (WHO) and United Nations Environment Programme (UNEP) published a report emphasizing that endocrine-disrupting chemicals are one of the major emerging global public health threats. In 2015, the International Federation 
of Gynecology and Obstetrics called for timely action to prevent health hazards associated with EDCs exposure. In July 2018, the American Academy of Pediatrics raised the alarm about the usage of numerous synthetic chemicals urging policymakers to act. The scientific community is urged to contribute to global efforts by expanding collaboration between academics, government regulators, and industry. The end goal of these combined efforts is for the "five centuries of the plastic kingdom" to be replaced by safer everyday products. Instructions should focus on reducing the production and use of EDCs in any form. This includes industrial production of fewer plastic bottles, metal food cans, harmful household detergents, and increasing production of BPA-free food, phthalate-free toys, parabens-free drugs, and cosmetics in accordance. The informed consumer's power is critical in this fight that demands lifelong training, that can be achieved through a spiral curriculum at nursery school, kindergarten, school, parents associations, and eco-communities. The messages must not frighten the population but provide sound and useful information (13-15). EDCs literacy will become a feasible goal if government action provides its support, particularly in local regions and municipalities following EU Environment Protection, Regulation Strategies, and in collaboration with the Chemicals World Industry. Examples of sound policymaking are the ban on bisphenol A in 2015 and diethylstilbestrol in the '70s. Public health infrastructure and climate change environmental protection, therefore, are fundamental pillars of this fight. EDCs disease burden and cost should also be considered, for example, a significant intellectual disability that may arise due to the exposure to polybrominated diphenyl ethers, mainly in the USA. Another example is the cost of exposure to organophosphate pesticides, the main contributors to costs related to EDCs exposure in the European Union (11). However, the reality practicum vs. optimum means that in the multifaceted global chemicals milieu, e.g., home kids devices (phthalates), food (BPA), and flame retardants, zero-risk is utopia.

\section{CONCLUSION}

Considering the current information gap between basic research, commercial classification, and government regulations, further research is needed on EDC's impact on the environment and public health. Moreover, the scientific and regulatory agencies of the EU (CHAFEA, ECHA, EFSA) (10) must improve the risk assessment procedures in collaboration and coordination with stakeholders, university networks equipped with accredited, remote-area quality control (internal and external quality assessment), quality accreditation (Lessons from European Community: Missions in Iran) and collaboration with established reference labs (aflatoxins control in Iran pistachio production procedures) beyond borders, concerning the monitoring and surveillance local worldwide crops production, always for public health human and wildlife benefit.

\section{REFERENCES}

1. Monneret C. What is an endocrine disruptor? [Internet]. Vol. 340, Comptes Rendus - Biologies. Academie des sciences; 2017. p. 403-5. Available from: http://dx.doi. org/10.1016/j.crvi.2017.07.004

2. Kanno J. Introduction to the concept of signal toxicity. J Toxicol Sci. 2016;41(Special Issue):SP105-9.

3. Organization WH, Programme UNE, for the Sound Management of Chemicals I-OP, Bergman $\AA$, Heindel JJ, Jobling $S$, et al. State of the science of endocrine disrupting chemicals 2012 / edited by Åke Bergman ... [et al]. World Health Organization; 2013. xxv, 260 p.

4. Robinson L, Miller R. The Impact of Bisphenol $A$ and Phthalates on Allergy, Asthma, and Immune Function: a Review of Latest Findings. Vol. 2, Current environmental health reports. 2015. p. 379-87.

5. Rice C, Birnbaum LS, Cogliano J, Mahaffey K, Needham L, Rogan WJ, et al. Endocrine Disruptors | Mini-Monograph Exposure Assessment for Endocrine Disruptors: Some Considerations in the Design of Studies. 2003;111(13):1683-90.

6. Browne P, Noyes PD, Casey WM, Dix DJ. Application of adverse outcome pathways to U.S. EPA's endocrine disruptor screening program [Internet]. Vol. 125, Environmental Health Perspectives. 2017. p. 096001. Available from: https://ehp.niehs.nih.gov/doi/10.1289/EHP1304

7. Thodis A, Itsiopoulos C, Kouris-Blazos A, Brazionis L, Tyrovolas S, Polychronopoulos E, et al. Observational study of adherence to a traditional Mediterranean diet, sociocultural characteristics and cardiovascular disease risk factors of older Greek Australians from MEDiterranean ISlands (MEDIS-Australia Study): Protocol and rationale. Nutr Diet. 2018;75(1):44-51.

8. Kahn JS, Mclntosh K. History and recent advances in coronavirus discovery. Pediatr Infect Dis J. 2005;24:S223S226.

9. Bauchner H, Fontanarosa PB, Livingston EH. Conserving Supply of Personal Protective Equipment-A Call for Ideas. JAMA. 2020;323(19):1911

10. Gore A, Crews D, Doan L, La Merrill M, Patisaul H ZA. Introduction To Endocrine Disrupting Chemicals(EDCs) A Guide For Public Interest Organizations And PolicyMakers. Endocrine Society 2014 pp 1-76;

11. Holmes D. Endocrine disruptors cause toxic fallout [Internet]. Vol. 1, The Lancet Diabetes and Endocrinology. Elsevier Ltd; 2013. p. 93-4. Available from: http://dx.doi. org/10.1016/S2213-8587(13)70057-3

12. Altenburger R, Scholze M, Busch W, Escher BI, Jakobs G, Krauss $M$, et al. Mixture effects in samples of multiple contaminants - An inter-laboratory study with manifold bioassays. Environ Int. 2018;114:95-106.

13. Mughal BB, Demeneix BA, Fini JB. Evaluating thyroid disrupting chemicals in vivo using xenopus laevis. In: Methods in Molecular Biology. 2018. p. 183-92. 
14. Mughal BB, Fini JB, Demeneix BA. Thyroid-disrupting chemicals and brain development: An update. Vol. 7, Endocrine Connections. 2018. p. R160-86.

15. Ann M, Corresp O, Flynn K, Olmstead A, Goumelon A, Degitz $S$, et al. Endocrine disruption: Where are we now : Tier 2 testing. 2016;2.

16. Vandenberg LN. Non-monotonic dose responses in studies of endocrine disrupting chemicals: Bisphenol a as a case study. Dose-Response. 2014;12(2):259-76.

17. Zhou J, del Rosal B, Jaque D, Uchiyama S, Jin D. Advances and challenges for fluorescence nanothermometry. Nat Methods [Internet]. 2020;17(10):967-80. Available from: http://dx.doi.org/10.1038/s41592-020-0957-y
18. Bergman $\AA$, Heindel JJ, Kasten T, Kidd KA, Jobling $\mathrm{S}$, Neira $M$, et al. Perspectives | Editorial The Impact of Endocrine Disruption: A Consensus Statement on the State of the Science. 2013;121(4):104-7.

19. Alimentaires $L n^{\circ} 2010-729$ du 30 juin 2010 tendant à suspendre la commercialisation de tout conditionnement comportant du bisphénol $\mathrm{A}$ et destiné à recevoir des produits alimentairesLOI $n^{\circ} 2010-729$ du 30 juin 2010 tendant à suspendre la commercialisation de tout cond. https://www.legifrance.gouv.fr/loda/id/JORFTEXT000022414734/2021-01-05/.

\section{Hemikalije koje narušavaju endokrini sistem: Uticaj na javno zdravlje}

'Evangelos A Polychronopoulos, ${ }^{1}$ George K Balias, ${ }^{1}$ Maria

Skouroliakou, 'Chrysa Kapartziani, 1,3Paraskevi D Kalofiri, ${ }^{2}$ Michail Rallis

'Harokopio University, Department of Nutrition and Dietetics

${ }^{1}$ Harokopio University, Department of Geography

${ }^{2}$ National and Kapodistrian University, Department of Pharmaceutics 3University of West Attica, Department of Biomedical Sciences

\begin{abstract}
Kratak sadržaj
Endokrini disruptori su kontroverzna tema u naučnim, pravnim, socijalnoekonomskim i zdravstvenim krugovima. Životna sredina svake zajednice trenutno je pod opsadom različitih supstanci koje remete funkcionisanje endokrinog sistema, od kojih su mnoge još uvek nepoznate. Endokrini disruptori utiču na normalnu funkciju endokrinog, nervnog i imunskog sistema, ometajući rast i reprodukciju i smanjujući dužinu života. Izvan svake sumnje, štetni efekti endokrinih disruptora posledica su svakodnevnog, višestrukog izlaganja stotinama hemikalija u nepoznatim dozama, kao što su: pesticidi, insekticidi, policiklični aromatični ugljovodonici, dioksini, polihlorisani bifenili, dihlorodifeniltrihloroetan, brominovani usporivači plamena i parabeni. Imajući u vidu da hiljade potencijalnih endokrinih disruptora promakne i naučnoj i medicinskoj zajednici zbog još uvek neprevaziđenih metodoloških poteškoća u ovom polju, trenutna situacija je prilično zabrinjavajuća. Svetska zdravstvena organizacija je 2012. godine objavila izveštaj u kome je istaknuto da su endokrini disruptori jedna od glavnih globalnih pretnji javnom zdravlju. Zajedničko delovanje informisanih potrošača, industrijskih inovacija i zakonskih regulativa biće glavna pokretačka struja za rešavanje ovog problema. Stoga su napredak u naučnim istraživanjima, stabilna zdravstvena infrastruktura i agencije za zaštitu životne sredine osnovni stubovi u borbi protiv sve većeg problema koji predstavljaju endokrini disruptori.
\end{abstract}

Ključne reči: Endokrini disruptori; Javno zdravlje; COVID-19. 